Article

\title{
Feeding Delivery of dsHvSnf7 Is a Promising Method for Management of the Pest Henosepilachna vigintioctopunctata (Coleoptera: Coccinellidae)
}

\author{
Jing Lü 1,2, Zhuoqi Liu 1,2, Wei Guo ${ }^{1,2}$, Mujuan Guo ${ }^{1,2}$, Shimin Chen ${ }^{1,2}$, Huali Li $^{3}$, \\ Chunxiao Yang ${ }^{3}$, Youjun Zhang ${ }^{4, *(\mathbb{D})}$ and Huipeng Pan ${ }^{1,2, *(\mathbb{D})}$ \\ 1 Key Laboratory of Bio-Pesticide Innovation and Application, South China Agricultural University, \\ Guangdong Province, Guangzhou 510642, China; 13556143025@stu.scau.edu.cn (J.L.); \\ liuzhuoqi@stu.scau.edu.cn (Z.L.); gwei8290@stu.scau.edu.cn (W.G.); \\ 13265915482@stu.scau.edu.cn (M.G.); smchen@stu.scau.edu.cn (S.C.) \\ 2 Engineering Research Center of Biocontrol, Ministry of Education and South China Agricultural University, \\ Guangdong Province, Guangzhou 510642, China \\ 3 State Key Laboratory for Conservation and Utilization of Subtropical Agro-bioresources, \\ South China Agricultural University, Guangzhou 510642, China; hualili@scau.edu.cn (H.L.); \\ yangchunxiao@scau.edu.cn (C.Y.) \\ 4 Department of Plant Protection, Institute of Vegetables and Flowers, Chinese Academy of Agricultural \\ Sciences, Beijing 100081, China \\ * Correspondence: zhangyoujun@caas.cn (Y.Z.); panhuipeng@scau.edu.cn (H.P.)
}

Received: 16 December 2019; Accepted: 30 December 2019; Published: 31 December 2019

\begin{abstract}
RNA interference (RNAi) techniques have emerged as powerful tools in the development of novel management strategies for the control of insect pests, such as Henosepilachna vigintioctopunctata, which is a major solanaceous pest in Asia. Our results showed that levels of HvSnf7 expression were greater in larval midguts than in other tissues. Silencing of HvSnf7 led to greater H. vigintioctopunctata mortality rates and appeared to be time- and partially dose-dependent. Bacterially expressed dsHvSnf7 that was applied to detached plant leaves caused 98, 88, and 60\% mortality in 1st and 3rd instars, and adults after 10,12, and $14 \mathrm{~d}$, respectively; when applied to living plants, bacterially expressed dsHvSnf7 led to mortality in 1st and 3rd instars, with no effect on adults. Bacterially expressed dsHvSnf7 led to improved plant protection against $H$. vigintioctopunctata. Ultrastructural changes caused by HvSnf7-RNAi in larval midguts showed extensive loss of cellular contents that indicate loss of membrane integrity. This study indicate that HvSnf7 potentially can be used as RNAi target gene for controlling of $H$. vigintioctopunctata.
\end{abstract}

Keywords: Henosepilachna vigintioctopunctata; HvSnf7; feeding RNAi; mortality; ultrastructural change

\section{Introduction}

RNA interference (RNAi) is a sequence-specific method for the inhibition of target gene expression that may be used in the exploitation of species-specific and sustainable insect pest control [1-4]. RNAi-based products are expected to reach the market in the form of transgenic plants and non-transgenic alternatives, such as the spray application of double-strand RNA (dsRNA) to crops to induce silencing of specific genes [5,6]. In the past decade, a number of studies have been published on the application of RNAi for the control of pests from a wide range of insect orders, including the Coleoptera, Diptera, Hemiptera, Lepidoptera, and Orthoptera [7-14]; coleopterans, such as the western corn rootworm (Diabrotica virgifera virgifera) [7], the red flour beetle (Tribolium castaneum), and Colorado potato beetle (Leptinotarsa decemlineata) [15] have been shown to be highly susceptible to dsRNAs. 
Henosepilachna vigintioctopunctata (Fabricius) (Coleoptera: Coccinellidae) is one of the most economically important insect pests in Asia, causing significant damage to vegetables, particularly those in the Solanaceae [16,17]. Currently, this species is mainly controlled by chemical pesticides [18]; however, against the background of the requirement for negative growth of pesticide use in China, there is an urgent need to develop non-chemical pest-specific alternatives with new modes of action for the control of $H$. vigintioctopunctata.

Endosomal sorting complexes required for transport (ESCRTs), which were first discovered in yeast, are required in multivesicular body (MVB) biogenesis [19], and as such, the ESCRT pathway is a key regulator of biological processes important for eukaryotic cell growth and survival. In yeast, humans, and insects, the ESCRT pathway is composed of five distinct, highly conserved sub-complexes: ESCRT-0, -I, -II, and -III, and VPS4-Vta1 [20]. ESCRT-III, the final complex in the MVBs degradation pathway, provides the core machinery that mediates membrane deformation and fission events during MVB biogenesis [21]. ESCRT-I and -III components have been found to localize to the midbody, and ESCRT-III components have been proposed to mediate membrane fission at the end of cytokinesis [22-25]. The vacuolar sorting protein Snf7 is an essential cellular component of ESCRT-III complex in multiple organisms that is involved in the sorting of transmembrane proteins en-route to lysosomal degradation through the endosomal-autophagic pathway [26]. Previous studies have demonstrated Snf7 is an effective RNAi target for the control of pests, such as $D . v$. virgifera LeConte $[7,26,27]$ and the southern corn rootworm $D$. undecimpunctata howardi [28]. The first commercially available genetically modified maize variety, MON87411, which includes an RNAi trait targeting D. v. virgifera Snf7 against D. v. virgifera, was deregulated in the US in 2017 [29], and although the function of the Snf7 protein is conserved, suppression of the Snf7 gene in D. v. virgifera via dsSnf7 is sequence-specific [30].

In this study, we evaluated the potential of the target gene HvSnf7 in the control of H. vigintioctopunctata. Specifically, we (1) investigated expression patterns of HvSnf7 across developmental stages and among tissues; (2) tested effects of oral ingestion of synthesized dsHvSnf7 concentrations on in vitro neonate survival rates and HvSnf gene expression; (3) quantified effects on larval and adult survival rates of ingestion of bacterially expressed dsHvSnf7; and (4) explored effects on ultrastructural changes to the larval midgut of ingestion of dsHvSnf7.

\section{Materials and Methods}

\subsection{Insects}

Henosepilachna vigintioctopunctata was collected from Solanum nigrum (L.) in April 2018 at the South China Agricultural University campus, Guangzhou City [31] and reared and maintained on detached Solanum melongena leaves in petri-dishes in an incubator set at $25 \pm 1{ }^{\circ} \mathrm{C}, 14 \mathrm{~L}: 10 \mathrm{D}$, and $80 \%$ $\mathrm{RH}$, before and during experiments.

\subsection{Sample Preparation for Analysis of Hvsnf7 Expression}

Samples of $H$. vigintioctopunctata at the egg, instar $(\times 4)$, pupal, and adult (female and male) life history stages were collected as described in our recent study [31]. Tissue, comprising cuticle, fat body, midgut, and malpighian tubule, was dissected from 4th instar larvae, as described previously [31]. Each experiment was replicated three times. All the samples were quickly frozen in $1.5 \mathrm{~mL}$ tubes by liquid nitrogen, and stored at $-80^{\circ} \mathrm{C}$ before the total RNA extraction.

\subsection{RNA Extraction and $C D N A$ Synthesis}

Total RNAs were isolated using TRIzol reagent (Invitrogen, Carlsbad, CA, USA) as previously described in our recent study [32]. A NanoDrop One ${ }^{C}$ spectrophotometer (Thermo Fisher Scientific, Waltham, MA, USA) was used to ascertain RNA concentration. First-strand cDNA was synthesized from $1.0 \mu \mathrm{g}$ of total RNA in $20 \mu \mathrm{L}$ volume using the PrimeScript reverse transcriptase (RT) kit 
(containing gDNA Eraser, Perfect Real Time, TaKaRa, Dalian, China) according the manufacturer's recommendations. The cDNA was diluted 10-fold for the subsequent general polymerase chain reaction (PCR), reverse transcriptase-quantitative polymerase chain reaction (RT-qPCR), and dsRNA synthesis experiments.

\section{4. dsRNA Preparation}

Specific primers containing a T7 promoter sequence were used to generate dsRNAs against HvSnf7 and green fluorescent protein (GFP) (Table 1). PCR products, which were purified using a Universal DNA Purification Kit (TIANGEN, Beijing, China), were used as a template to generate dsRNA using a T7 MEGAscript kit (Thermo Fisher Scientific) following the manufacturer's protocol. Synthesized dsRNAs were suspended in $\mathrm{ddH}_{2} \mathrm{O}$, and size and integrity of the purified dsRNAs were confirmed by loading the suspension onto a $1.5 \%$ agarose/Tris-acetate-EDTA (TAE) gel stained with GoldView I. Concentrations of purified dsRNAs were measured using a NanoDrop One $\mathrm{C}^{\mathrm{C}}$ spectrophotometer (Thermo Fisher Scientific), and the purified dsRNAs were stored at $-20^{\circ} \mathrm{C}$ prior to use.

Table 1. Primers used for this study.

\begin{tabular}{cc}
\hline Gene & Primer Sequences $\mathbf{( 5}^{\prime} \mathbf{- 3}^{\prime} \mathbf{)}$ \\
\hline HvSnf7-RT-qPCR-F & CAGAGAGGAACACTAGAGGAA \\
HvSnf7-RT-qPCR-R & GGTCAACGTTCATGTGTTTATG \\
dsHvSnf7-F & TAATACGACTCACTATAGGGACCCTTACAACCCTTGAATTAC \\
dsHvSnf7-R & TAATACGACTCACTATAGGGCTTCATCATCTTCCACTGCTT \\
dsGFP-F & TAATACGACTCACTATAGGGCTTGAAGTTGACCTTGATGCC \\
dsGFP-R & TAATACGACTCACTATAGGGTGGTCCCAATTCTCGTGGAAC \\
L4440-HvSnf7-F & ATCATCGATGAATTCACCCTTACAACCCTTGAATTAC \\
L4440-HvSnf7-R & TTCCTGCAGCCCGGGCTTCATCATCTTCCACTGCTT \\
L4440-GFP-F & ATCATCGATGAATTCCTTGAAGTTGACCTTGATGCC \\
L4440-GFP-R & TTCCTGCAGCCCGGGTGGTCCCAATTCTCGTGGAAC \\
\hline
\end{tabular}

\subsection{Effects of Oral Ingestion of dsRNAs on Neonate Development and HvSnf Gene Expression}

To assess effects of dsRNAs on larvae development, 12-mm diameter leaf-discs of S. melongena were immersed in one of three concentrations of dsHvSnf7 $(5,10$, and $50 \mathrm{ng} / \mu \mathrm{L})$ or $50 \mathrm{ng} / \mu \mathrm{L}$ of dsGFP for $10 \mathrm{~s}$ and supplied to five replicate Petri dishes containing 10 neonate larvae for $2 \mathrm{~d}$; then fresh, untreated leaves were provided ad libitum for an additional $8 \mathrm{~d}$. Larval mortality and developmental stages were recorded daily

To test for effects on HvSnf gene expression, neonate larvae were treated with either $10 \mathrm{ng} / \mu \mathrm{L}$ of $\mathrm{dsHvSnf7}$ or $10 \mathrm{ng} / \mu \mathrm{L}$ of dsGFP; three replicates of 10 individuals were collected from each treatment after 2 and $4 \mathrm{~d}$, flash-frozen in liquid nitrogen, and stored at $-80{ }^{\circ} \mathrm{C}$ in $1.5-\mathrm{mL}$ centrifuge tubes prior to total RNA extraction for analysis of HvSnf gene expression.

\section{HvSnf Gene Expression Analysis}

We analyzed HvSnf gene expression using RT-qPCR, using a reaction mixture and program that have been described previously [32] and gene-specific primers listed in Table 1. The reference genes RPS18 and RPL13 were used as internal controls [31] and relative quantification of $H v S n f 7$ was performed using the $2^{-\Delta \Delta C t}$ method [33].

\subsection{Effects of Bacterially Expressed dsHvSnf7 on H. vigintioctopunctata Mortality}

\subsection{1. dsRNA Synthesis in Bacteria}

Bacterially expressed dsHvSnf7 and dsGFP were synthesized as previously described [8] using gene-specific markers (Table 1). PCR products were reorganized into a linearized L4440 vector used the Trelief SoSoo Cloning kit (Ver.2, TSINGKE, Beijing, China), following the manufacturer's 
recommendations. Then, the L4440 vector containing the PCR products was transformed into competent HT115 (DE3) cells, strain of RNase III deficient Escherichia coli, and individual colonies were inoculated and grown until cultures reached an OD600 value of $0.5-0.8$, when they were induced to express dsRNA by the addition of IPTG to a final concentration of $1 \mathrm{mM}$. The expressed dsRNA was centrifuged at $5000 \times g$ for $10 \mathrm{~min}$, and the bacteria cells were resuspended in an equal original culture volume of $\mathrm{ddH}_{2} \mathrm{O}$.

\subsubsection{Effects on $H$. vigintioctopunctata Mortality}

Bacterially expressed dsRNAs were administered, via S. melongena leaves in Petri dishes, to five replicates of 10 individuals of 1st and 3rd instar larvae and adults that had been starved for $3 \mathrm{~h}$. We immersed 12-mm diameter leaf-discs of S. melongena in bacteria-expressed dsRNA solution for $10 \mathrm{~s}$; the discs were then place on filter paper and air dried at room temperature for $1 \mathrm{~h}$. Two leaf-discs were fed to 1st instar larvae, while 3rd instar larvae and adults were fed 20 leaf-discs; leaf-discs treated with dsRNA were replenished daily for two consecutive days, and from the third day onwards, insects were supplied with equal amounts of untreated fresh leaves. Assays continued for 10, 12, and $14 \mathrm{~d}$ for the 1st and 3rd instar larvae, and adults, respectively.

In a separate experiment, we placed three replicates of $10 \times 1$ st instar larvae, $5 \times 3$ rd instar larvae, and $5 \times$ adults to leaves of $S$. melongena plants that had been sprayed with bacterially expressed dsRNA for $1 \mathrm{~h}$; each leaf was covered with a mesh bag to prevent the escape of the insects and the plants were placed in a ventilated cage $(60 \times 40 \times 80 \mathrm{~cm})$ under field-realistic environmental conditions $\left(21-32^{\circ} \mathrm{C}\right)$. After $5 \mathrm{~d}$, mortality was recorded and the consumed leaves were photographed.

\subsection{Analysis of Larval Midgut Ultrastructure}

We treated 2 nd instar larvae with $10 \mathrm{ng} / \mu \mathrm{L}$ of in vitro synthesized dsRNAs or $10 \mathrm{ng} / \mu \mathrm{L}$ of dsGFP for two consecutive days. On the 5th day, 10 surviving individuals were collected from each treatment and dissected to obtain the midguts.

The midguts were cut into smaller pieces (0.2-mm long) and prepared using fixing, embedding, and slicing methods previously described [34]. Samples were observed using a Talos L120C transmission electron microscope (Thermo Fisher Scientific) and images were recorded using an AMT digital image capturing system at optimal magnification (range of $\times 1600$ to 5300 ).

\subsection{Data Analysis}

One-way analysis of variance (ANOVA) was used to compare $H v S n f 7$ expression levels across developmental stages and among tissue types, and to test for treatment effects on levels of $\mathrm{HvSnf7}$ gene expression at each time point and on larvae and adult mortality on the living plants. Means were compared using Tukey's test at $p<0.05$. Variation in target genes between the control and treatment was tested using ANOVA (Breslow pairwise comparison, $p<0.05$ ). Survival curves, based on larval and adult mortality, were created using the Cox regression program. Proportional data were arcsine square root-transformed prior to analysis and data were analyzed using SPSS (v. 21.0; IBM Corp., Armonk, NY, USA).

\section{Results}

\subsection{Temporal and Tissue Expression of HvSnf7}

The results showed differences in HvSnf7 expression across development stages $\left(\mathrm{F}_{7,16}=3.155\right.$, $p=0.027)$ and among tissue types $\left(\mathrm{F}_{3,8}=20.694, p<0.0001\right)$, where lowest and greatest levels of expression were at the egg and 2nd instar stages, respectively; there were no differences in levels of gene expression among the other development stages (Figure 1A). Levels of expression of HvSnf7 were greater in the midgut than in other tissues (Figure 1B). 
(A)

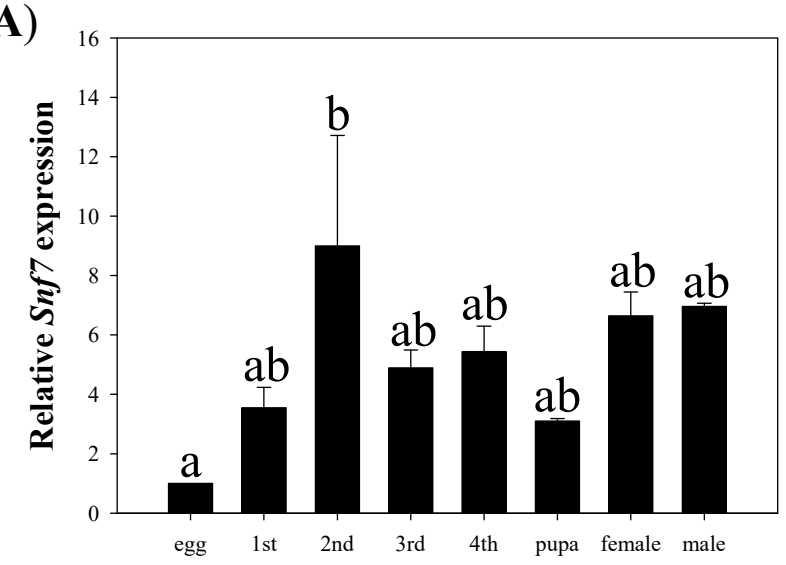

(B)

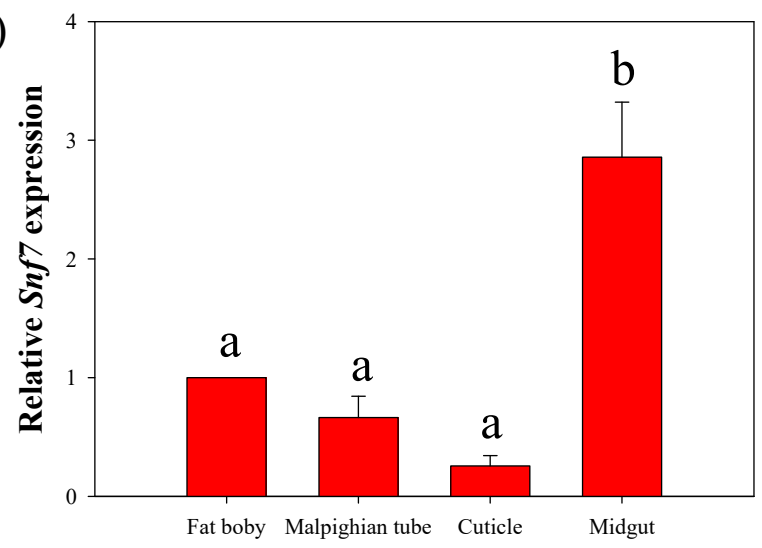

Figure 1. Expression patterns of $H v S n f 7$ across different developmental stages (A) and among tissues (B) in H. vigintioctopunctata. Data are means + starndard error (SE) and different letters indicate differences in gene expression at $p<0.05$.

\subsection{Effects of Consumption of In Vitro Synthesized dsHoSnf7}

Oral consumption of all concentrations of dsHvSnf7 led to greater overall levels of mortality after $10 \mathrm{~d}\left(\chi^{2}=84.235, d f=3, p<0.0001\right)$, where there were 22.8, 16.8, and 10.0-fold increases in mortality following consumption of $50 \mathrm{ng} / \mu \mathrm{L}(p<0.0001, \operatorname{Exp}(\mathrm{B})=22.767), 10 \mathrm{ng} / \mu \mathrm{L}(p<0.0001, \operatorname{Exp}(\mathrm{B})=16.768)$, and $5 \mathrm{ng} / \mu \mathrm{L}(p<0.0001, \operatorname{Exp}(B)=9.982)$ of dsHvSnf7 (Figure 2). Mortality was greater at 50 and $10 \mathrm{ng} / \mu \mathrm{L}$ of dsHvSnf7 than at $5 \mathrm{ng} / \mu \mathrm{L}\left(\mathrm{F}_{3,196}=67.621, p<0.0001\right)(78,70$, and $54 \%$, respectively) after $10 \mathrm{~d}$.

Levels of HvSnf7 expression were suppressed at days $2\left(\mathrm{~F}_{1,4}=8186.122, p<0.0001\right)$ and $4\left(\mathrm{~F}_{1,4}=\right.$ 10947.665, $p<0.0001$ ), where levels were suppressed 19.32 and 9.99-fold, respectively (Figure 3). 


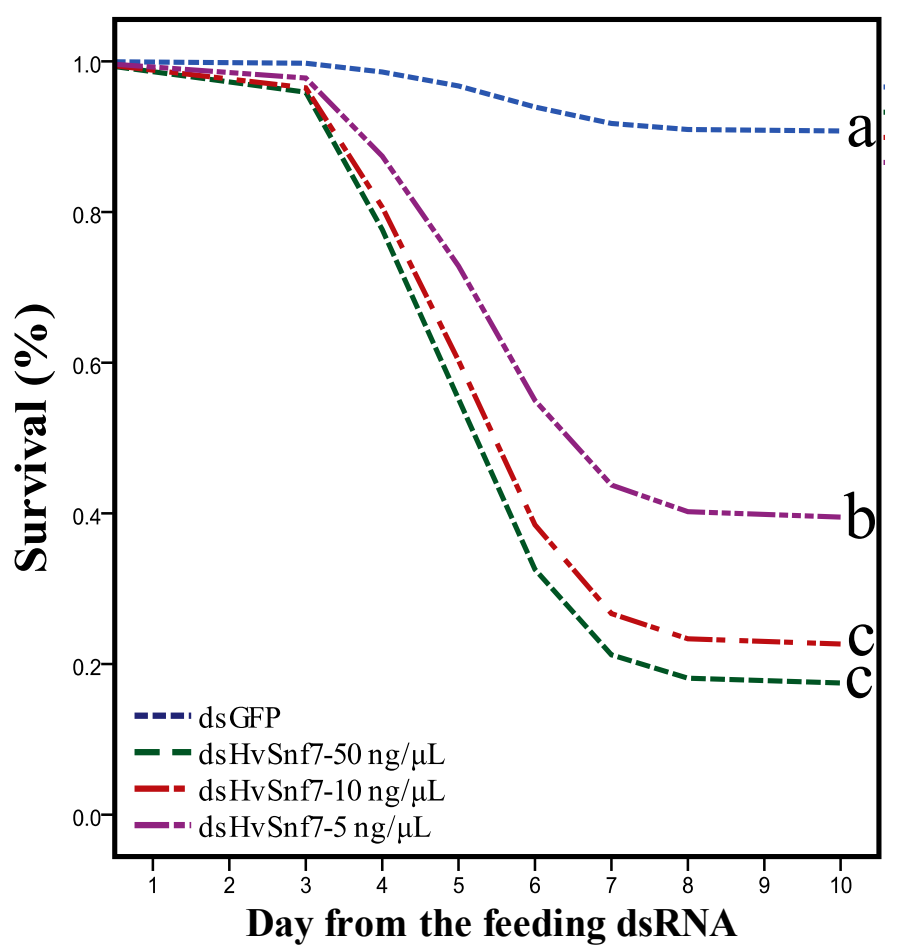

Figure 2. Impact of $H v S n f 7$ silencing using in vitro synthesized dsRNAs on $H$. vigintioctopunctata survival over $10 \mathrm{~d}$. Different letters indicate treatment differences at $p<0.05$.

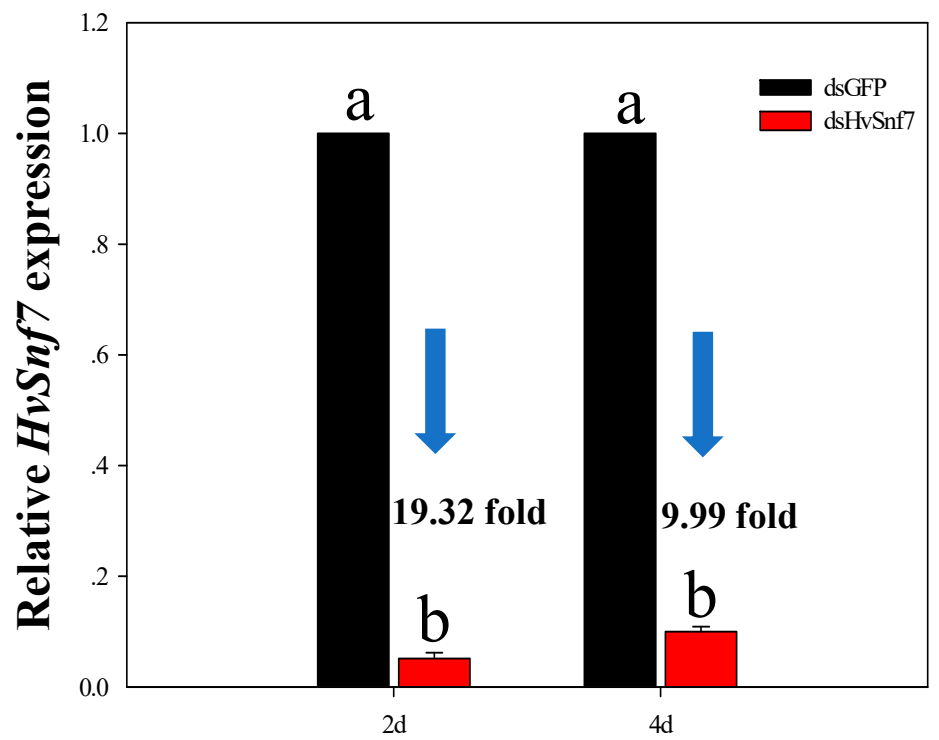

Day from the feeding dsRNA

Figure 3. Expression of $\mathrm{HvSnf7}$ in $\mathrm{H}$. vigintioctopunctata at 2 and $4 \mathrm{~d}$ after ingestion of in vitro synthesized dsHvSnf7 and dsGFP (10 ng/ $\mu \mathrm{L})$. Transcript levels of HvSnf7 in dsGFP control larvae at each time point were set to 1 . Data are means $+\mathrm{SE}$ and different letters indicate differences among treatments at $p<0.05$.

\subsection{Impacts of Ingestion of Bacterially Expressed dsHvSnf7 on H. vigintioctopunctata Survival}

We found that 1st and 3rd instar larvae, and adults began to die on the 2nd, 3rd, and 5th days after consumption of bacterially expressed dsHvSnf7 that caused 98\% $(p<0.0001, \operatorname{Exp}(\mathrm{B})=21.452), 88 \%$ $(p<0.0001, \operatorname{Exp}(\mathrm{B})=15.624)$, and $60 \%(p=0.007, \operatorname{Exp}(\mathrm{B})=5.537)$ mortality, respectively, by the end of the experiment (after 10,12, and $14 \mathrm{~d}$, respectively) (Figure 4). Compared with the control, ingestion of 
bacterially expressed dsHvSnf7 led to 21.452, 15.624, and 5.537-fold increases in mortality for 1st and 3rd instars, and adults, respectively.
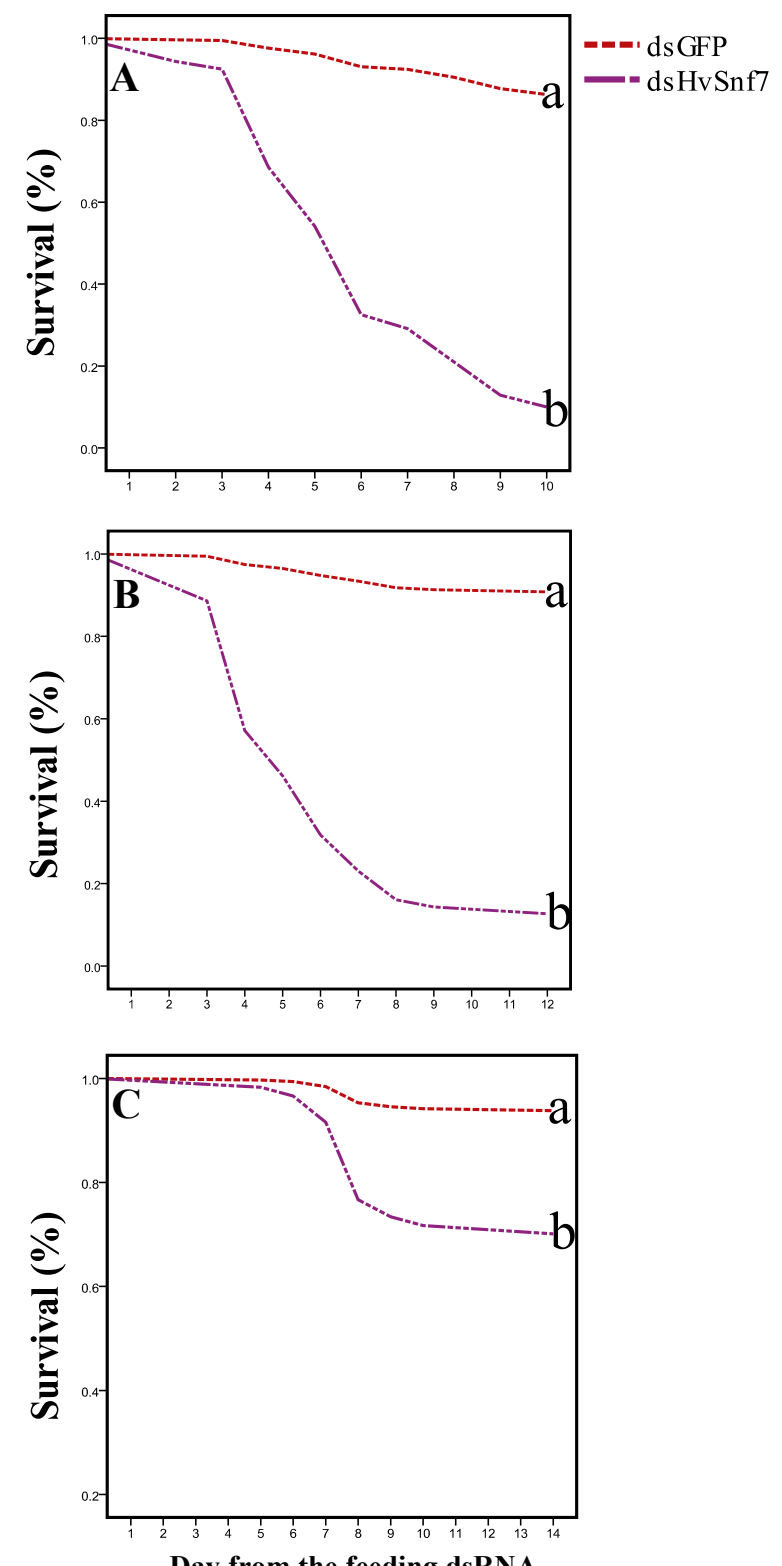

Figure 4. Impact of HvSnf7 silencing on survival rates of 1st instar larvae (A), 3rd instar larvae (B), and adults (C) fed on detached leaves treated with bacterially expressed dsHvSnf7 at 10, 12, and $14 \mathrm{~d}$, respectively. Different letters indicate treatment differences at $p<0.05$.

We also found mortality effects for 1 st $\left(77 \% ; F_{1,4}=180.500, p<0.0001\right)$ and $3 r d\left(53 \% ; F_{1,4}=45.000\right.$, $p=0.003$ ) instars feeding on $S$. melongena plants treated with bacterially expressed dsHvSnf7 after $5 \mathrm{~d}$; however, there were no effects of mortality on adults $\left(13 \% ; \mathrm{F}_{1,4}=4.000, p=0.116\right)$ (Figure $\left.5 \mathrm{~A}\right)$. Plants treated with dsHvSnf7 resulted in lower levels of $H$. vigintioctopunctata leaf damage (Figure 5B). 
A

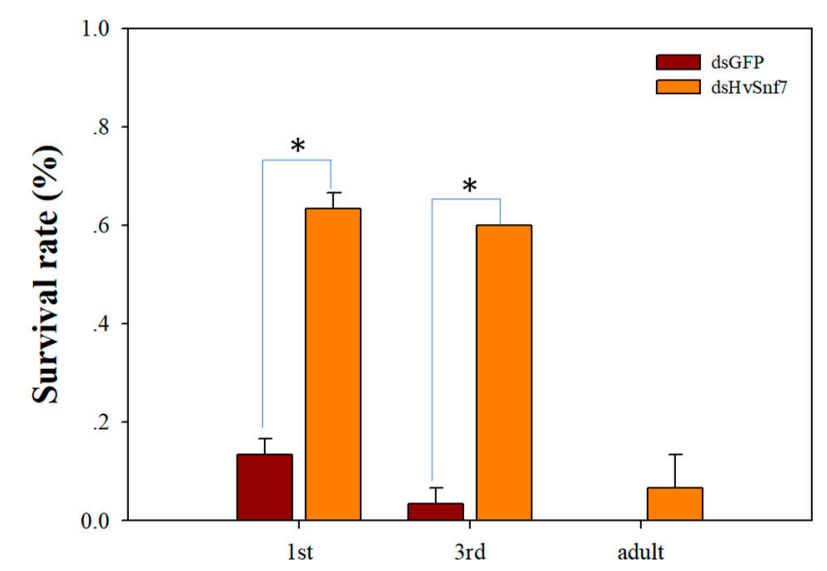

B

$1^{\text {st }}$ instar

\section{dsHvSnf7}

dsGFP

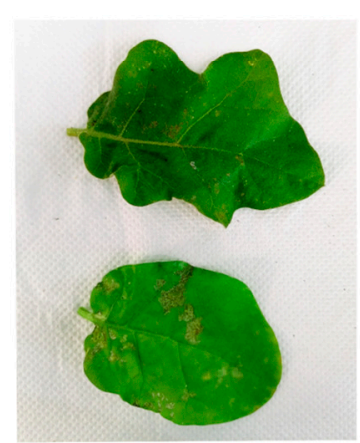

$3^{\text {rd }}$ instar

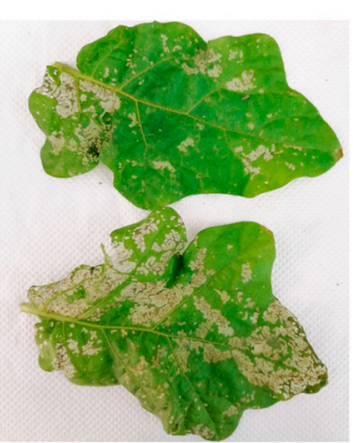

Adult

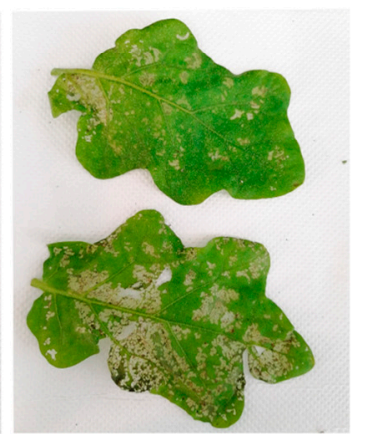

Figure 5. Impact of $H v S n f 7$ silencing on survival rates of larvae and adults fed on living plants treated with bacterially expressed dsHvSnf7 (A) and associated damage caused to leaves (B). * Treatment differences at $p<0.05$.

\subsection{HvSnf7 Silencing Effects on Larval Midgut Ultrastructure}

Electron microscopy of dsGFP-treated enterocytes revealed the presence of intact basement and peritoneal membranes; however, silencing of $\mathrm{HvSnf7}$ led to losses in integrity of enterocyte membranes. There was rupturing of the cell basement membrane, and boundaries between the cell internal chambers were damaged in dsHvSnf7-treated enterocytes. Ubiquitinated integral membrane proteins could not be sequestered by the fusion of MVB to autophagosomes and lysosomes; thus, membrane integrity was destroyed, and membrane receptor proteins and endocytosed materials, which were not subject to autophagic degradation, induced greater amounts of impurities in the cytoplasm (Figure 6). 


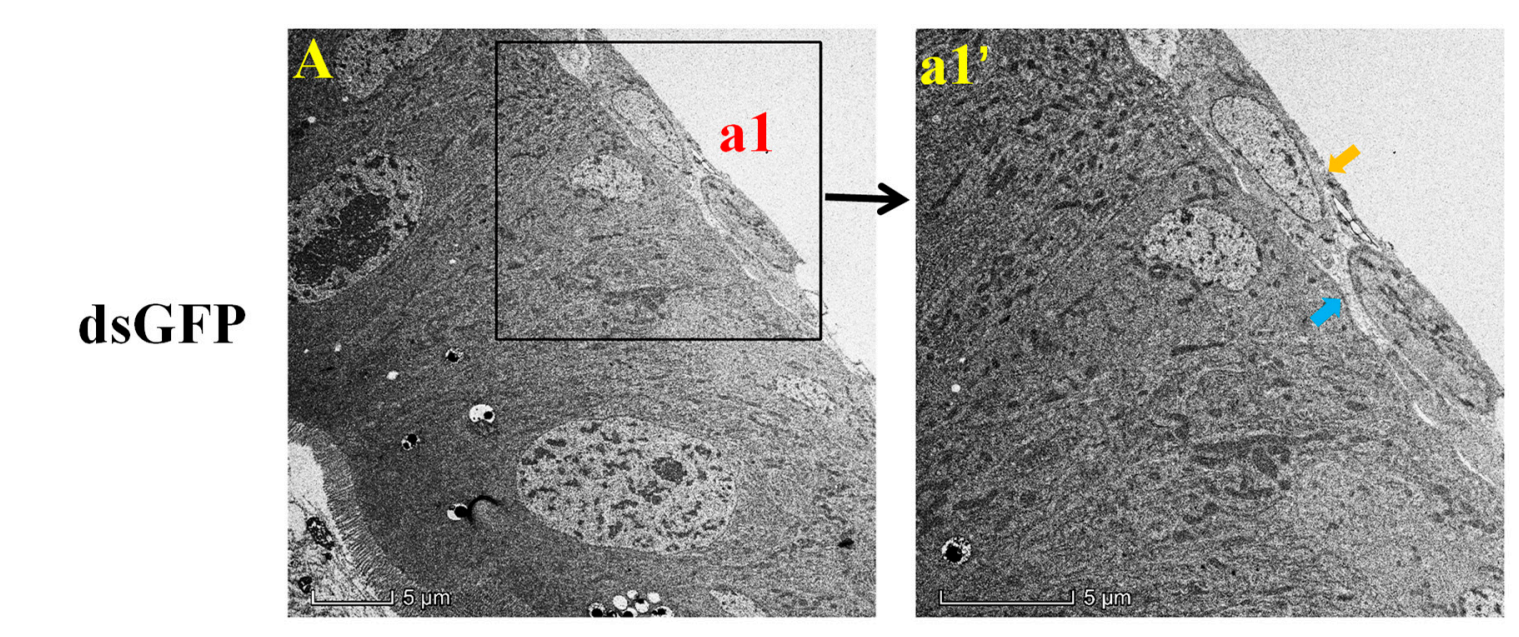

dsHvSnf7
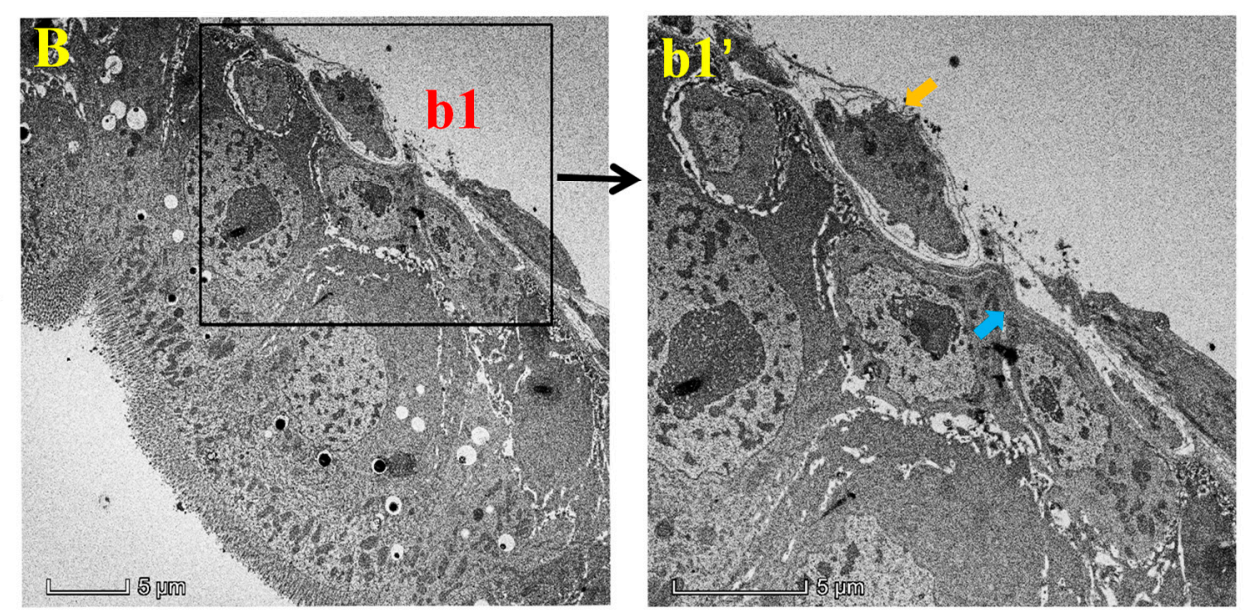

Figure 6. HvSnf7 RNAi-mediated ultrastructural changes in larval midguts following ingestion of in vitro synthesized dsHvSnf7 and dsGFP $(10 \mathrm{ng} / \mu \mathrm{L})$. a1' and b1' are for the magnified view of a1 and $\mathrm{b} 1$, respectively. Blue indicates cell basement membrane; yellow indicates cell peritoneal membrane.

\section{Discussion}

This study demonstrated the effects of RNAi on H. vigintioctopunctata larvae and adults exposed to dsRNA, by feeding in vitro synthesized and bacterially expressed dsHvSnf7 on detached leaves and living plants. Knockdown of HvSnf7 caused high levels of mortality in H. vigintioctopunctata, indicating its potential use as an RNAi target gene for the control of this insect pest.

In insects, Snf7 functions as a part of the ESCRT pathway that plays a crucial role in cellular housekeeping by internalization, transport, sorting, and lysosomal degradation of transmembrane proteins [20]. It has previously been shown that malfunctioning of these cellular processes in midgut and body fat tissues triggered by Snf7 RNAi were the key drivers of mortality in D. v. virgifera [26], and the critical function of $S n f 7$ in insect midgut cells was confirmed by changes in D. v. virgifera Snf7 larval enterocytes ultrastructure that underpin the conserved essential function of the ESCRT pathway in autophagy and membrane stability in other organisms [34]. Indeed, our results revealed that Snf7 was highly expressed in the midgut of $H$. vigintioctopunctata, and electron microscopy of enterocytes revealed that dsHvSnf7 plays an important role in membrane stability. Specifically, cell homeostasis and integrity in dsGFP-treated enterocytes indicated that the autophagic degradation pathway continued to function properly; however, the structures of multi-lamellar bodies and macroautophagic complex in the midgut of dsHvSnf7-treated larvae were not detected, in contrast to a previous study [34]. The possible reasons for this difference include treatment duration, dsRNA dose, stage of insects, and study species. 
Previous studies have shown large differences in RNAi efficiency among insect species $[5,35,36]$. RNAi-mediated silencing effects are efficient and systemic in coleopteran insects [7,8,15], and similarly, we found high levels of RNAi effects in $H$. vigintioctopunctata, even under the in vitro synthesized dsRNA concentration of $5 \mathrm{ng} / \mu \mathrm{L}$. Therefore, there is great potential for the control of $H$. vigintioctopunctata using RNAi. We also found there was no difference in mortality effects of in vitro synthesized dsHvSnf7 concentrations of 50 and $10 \mathrm{ng} / \mu \mathrm{L}$, indicating saturation of RNAi machinery was between 5 and $10 \mathrm{ng} / \mu \mathrm{L}$.

This study provides evidence for the efficient induction of RNAi using bacteria to deliver dsRNA for the control of $H$. vigintioctopunctata, because bacterially produced dsRNAs inhibited growth and caused higher mortality in larvae and adults fed on detached leaves and living plants, resulting in improved plant protection. It is known that, prior to ingestion, dsRNA must be stable to generate an RNAi response in insects; however, factors, such as UV radiation and presence of microorganisms, degrade dsRNA in the environment, thus, it is possible that dsRNA modification or embedding by liposomes or nanoparticles may solve the problem of dsRNA degradation to improve RNAi efficiency [36]. Therefore, ensuring the stability of dsRNA in the environment should increase field control by dsHvSnf7 of larval and adult $H$. vigintioctopunctata.

One concern related to the use of dsRNA in pest management is the unintended effects on non-target organisms. One recent study evaluated the activity spectrum of dsSnf7 against $D . v$. virgifera for 14 insect species belonging to 10 families from four orders, and found it was narrow, with species taxonomically related to the target organism being relatively more susceptible [30]. Before dsHvSnf7 is used for field control of H. vigintioctopunctata, closely related non-target species that feed on Solanaceae plants and are exposed to insecticidal dsRNA should be assessed for potential risks of H. vigintioctopunctata-active dsHvSnf7 [37].

\section{Conclusions}

In summary, we identified and characterized an HvSnf7 gene in H. vigintioctopunctata and showed its silencing using RNAi caused high levels of mortality and inhibited growth. Our findings confirmed our hypothesis that HvSnf7 may be a potential target gene for RNAi-based control of the pest H. vigintioctopunctata.

Author Contributions: Conceptualization, H.P. and Y.Z.; methodology, H.P. and J.L.; validation, J.L., Z.L., W.G., M.G., S.C., and H.L.; formal analysis, H.P. and J.L.; investigation, J.L., Z.L., W.G., M.G., S.C., and H.L.; resources, H.P.; data curation, J.L., Z.L., W.G., M.G., S.C., and H.L.; writing-original draft preparation, H.P., C.Y., and J.L.; writing-review and editing, H.P., C.Y., and J.L.; supervision, H.P.; project administration, H.P.; funding acquisition, H.P. All authors have read and agreed to the published version of the manuscript.

Funding: This research was supported by the National Key R\&D Program of China (2017YFD0200900), National Natural Science Foundation of China (31972269), and GDUPS (2017). The granting agencies have no role in the study design, data collection and analysis, decision to publish, or preparation of the manuscript.

Acknowledgments: Special thanks to Xiaowei Yang (Cornell University) for his valuable comments on our earlier draft.

Conflicts of Interest: The authors have declared that no conflict of interest exists.

\section{References}

1. Fire, A.; Xu, S.; Montgomery, M.K.; Kostas, S.A.; Driver, S.E.; Mello, C.C. Potent and specific genetic interference by double-stranded RNA in Caenorhabditis elegans. Nature 1998, 391, 806-811. [CrossRef]

2. Burand, J.P.; Hunter, W.B. RNAi: Future in insect management. J. Invertebr. Pathol. 2013, 112, S68-S74. [CrossRef]

3. Katoch, R.; Sethi, A.; Thakur, N.; Murdock, L.L. RNAi for insect control: Current perspective and future challenges. Appl. Biochem. Biotech. 2013, 171, 847-873. [CrossRef]

4. Zhang, J.; Khan, S.A.; Heckel, D.G.; Bock, R. Next-generation insect-resistant plants: RNAi-mediated crop protection. Trends Biotechnol. 2017, 35, 871-882. [CrossRef] 
5. Zotti, M.; Dos Santos, E.A.; Cagliari, D.; Christiaens, O.; Taning, C.N.T.; Smagghe, G. RNA interference technology in crop protection against arthropod pests, pathogens and nematodes. Pest Manag. Sci. 2018, 74, 1239-1250. [CrossRef]

6. Cagliari, D.; Dias, N.P.; Galdeano, D. Management of pest insects and plant diseases by non-transformative RNAi. Front. Plant Sci. 2019, 10, 1319. [CrossRef]

7. Baum, J.A.; Bogaert, T.; Clinton, W.; Heck, G.R.; Feldmann, P.; Ilagan, O.; Johnson, S.; Plaetinck, G.; Munyikwa, T.; Pleau, M.; et al. Control of coleopteran insect pests through RNA interference. Nat. Biotechnol. 2007, 25, 1322-1326. [CrossRef] [PubMed]

8. Zhu, F.; Xu, J.; Palli, R.; Ferguson, J.; Palli, S.R. Ingested RNA interference for managing the populations of the Colorado potato beetle, Leptinotarsa decemlineata. Pest Manag. Sci. 2011, 67, 175-182. [CrossRef] [PubMed]

9. Zhang, J.; Khan, S.A.; Hasse, C.; Ruf, S.; Heckel, D.G.; Bock, R. Full crop protection from an insect pest by expression of long double-stranded RNAs in plastids. Science 2015, 34, 991-994. [CrossRef] [PubMed]

10. Osman, G.H.; Assem, S.K.; Alreedy, R.M.; El-Ghareeb, D.K.; Basry, M.A.; Rastogi, A.; Kalaji, H.M. Erratum: Development of insect resistant maize plants expressing a chitinase gene from the cotton leaf worm, Spodoptera littoralis. Sci. Rep. 2016, 6, 20449. [CrossRef]

11. Guan, R.; Li, H.; Miao, X. RNAi pest control and enhanced BT insecticidal efficiency achieved by dsRNA of chymotrypsin-like genes in Ostrinia furnacalis. J. Pest Sci. 2017, 90, 745-757. [CrossRef]

12. Ni, M.; Ma, W.; Wang, X.F.; Gao, M.J.; Dai, Y.; Wei, X.L.; Zhang, L.; Peng, Y.G.; Chen, S.Y.; Ding, L.Y. Next-generation transgenic cotton: Pyramiding RNAi and Bt counters insect resistance. Plant Biotechnol. J. 2017, 15, 1204-1213. [CrossRef] [PubMed]

13. Liu, F.Z.; Yang, B.; Zhang, A.H.; Ding, D.R.; Wang, G.R. Plant-mediated RNAi for controlling Apolygus lucorum. Front. Plant Sci. 2019, 10, 64. [CrossRef] [PubMed]

14. Gu, L.; Knipple, D.C. Recent advances in RNA interference research in insects: Implications for future insect pest management strategies. Crop Prot. 2013, 45, 36-40. [CrossRef]

15. Yoon, J.S.; Mogilicherla, K.; Gurusamy, D.; Chen, X.; Cheredy, S.C.R.R.; Palli, S.R. Double-stranded RNA binding protein, Staufen, is required for the initiation of RNAi in coleopteran insects. Proc. Natl. Acad. Sci. USA 2018, 115, 8334-8339. [CrossRef]

16. Wang, Z.L.; Li, C.R.; Yuan, J.J.; Li, S.X.; Wang, X.P.; Chi, H. Demographic Comparison of Henosepilachna vigintioctopunctata (F.) (Coleoptera: Coccinellidae) reared on three cultivars of Solanum melongena L. and a wild host plant Solanum nigrum L. J. Econ. Entomol. 2017, 110, 2084-2091. [CrossRef]

17. Zhou, L.; Xie, B.G.; Wang, X.P. Population dynamic of Henosepilachna vigintioctopunctatain different host plants in Jianghan plain. China J. North. Hort. 2015, 11, 103-105.

18. Tu, X.Y.; Wang, G.H. Research progress of bio-control of Henosepilachna vigintioctopunctata. Chin. Plant Prot. 2010, 30, 13-16.

19. Michelet, X.; Djeddi, A.; Legouis, R. Developmental and cellular functions of the ESCRT machinery in pluricellular organisms. Biol. Cell 2010, 102, 191-202. [CrossRef]

20. Li, Z.; Blissard, G. The vacuolar protein sorting genes in insects: A comparative genome view. Insect Biochem. Mol. Biol. 2015, 62, 211-225. [CrossRef]

21. Wollert, T.; Wunder, C.; Lippincott-Schwartz, J.; Hurley, J.H. Membrane scission by the ESCRT-III complex. Nature 2009, 458, 172-177. [CrossRef] [PubMed]

22. Carlton, J.G.; Martin-Serrano, J. Parallels between cytokinesis and retroviral budding: A role for the ESCRT machinery. Science 2007, 316, 1908-1912. [CrossRef] [PubMed]

23. Dukes, J.D.; Richardson, J.D.; Simmons, R.; Whitley, P. A dominant-negative ESCRT-III protein perturbs cytokinesis and trafficking to lysosomes. Biochem. J. 2008, 411, 233-239. [CrossRef] [PubMed]

24. Elia, N.; Sougrat, R.; Spurlin, T.A.; Hurley, J.H.; Lippincott-Schwartz, J. Dynamics of endosomal sorting complex required for transport (ESCRT) machinery during cytokinesis and its role in abscission. Proc. Natl. Acad. Sci. USA 2011, 108, 4846-4851. [CrossRef] [PubMed]

25. Guizetti, J.; Schermelleh, L.; Mantler, J.; Maar, S.; Poser, I.; Leonhardt, H.; Muller-Reichert, T.; Gerlich, D.W. Cortical constriction during abscission involves helices of ESCRT-III-dependent filaments. Science 2011, 331, 1616-1620. [CrossRef] [PubMed]

26. Ramaseshadri, P.; Segers, G.; Flannagan, R.; Wiggins, E.; Clinton, W.; Ilagan, O.; McNulty, B.; Clark, T.; Bolognesi, R. Physiological and cellular responses caused by RNAi-mediated suppression of Snf7 orthologue in western corn rootworm (Diabrotica virgifera virgifera) larvae. PLoS ONE 2013, 8, e54270. [CrossRef] 
27. Bolognesi, R.; Ramaseshadri, P.; Anderson, J.; Bachman, P.; Clinton, W.; Flannagan, R.; Ilagan, O.; Lawrence, C.; Levine, S.; Moar, W.; et al. Characterizing the mechanism of action of double-stranded RNA activity against western corn rootworm (Diabrotica virgifera virgifera LeConte). PLoS ONE 2012, 7, e47534. [CrossRef]

28. Pereira, A.E.; Vélez, A.M.; Meinke, L.J.; Siegfried, B.D. Sublethal effects of vATPase-A and Snf7 dsRNAs on biology of Southern corn rootworm, Diabrotica undecimpunctata howardi Barber. J. Econ. Entomol. 2017, 110, 2545-2553. [CrossRef]

29. Head, G.P.; Carroll, M.W.; Evans, S.P.; Rule, D.M.; Willse, A.R.; Clark, T.L.; Storer, N.P.; Flannagan, R.D.; Samuel, L.W.; Meinke, L.J. Evaluation of SmartStax and SmartStax PRO maize against western corn rootworm and northern corn rootworm: Efficacy and resistance management. Pest Manag. Sci. 2017, 73, 1883-1899. [CrossRef]

30. Bachman, P.M.; Bolognesi, R.; Moar, W.J.; Mueller, G.M.; Paradise, M.S.; Ramaseshadri, P.; Tan, J.; Uffman, J.P.; Warren, J.; Elizabeth Wiggins, B.; et al. Characterization of the spectrum of insecticidal activity of a double-stranded RNA with targeted activity against Western Corn Rootworm (Diabrotica virgifera virgifera LeConte). Transgenic Res. 2013, 22, 1207-1222. [CrossRef]

31. Lü, J.; Chen, S.M.; Guo, M.J.; Ye, C.Y.; Qiu, B.L.; Wu, J.H.; Yang, C.X.; Pan, H.P. Corrigendum: Selection and validation of reference genes for RT-qPCR analysis of the ladybird beetle Henosepilachna vigintioctopunctata. Front. Physiol. 2019, 10, 981. [CrossRef] [PubMed]

32. Pan, H.; Yang, X.; Bidne, K.; Hellmich, R.L.; Siegfried, B.D.; Zhou, X. Selection of reference genes for RT-qPCR analysis in the monarch butterfly, Danaus plexippus (L.), a migrating bio-indicator. PLoS ONE 2015, 10, e0129482. [CrossRef] [PubMed]

33. Livak, K.J.; Schmittgen, T.D. Analysis of relative gene expression data using real-time quantitative PCR and the $2^{-\Delta \Delta C t}$ method. Methods 2001, 25, 402-408. [CrossRef] [PubMed]

34. Koči, J.; Ramaseshadri, P.; Bolognesi, R.; Segers, G.; Flannagan, R.; Park, Y. Ultrastructural changes caused by Snf7 RNAi in larval enterocytes of western corn rootworm (Diabrotica virgifera virgifera Le Conte). PLoS ONE 2014, 9, e83985. [CrossRef]

35. Terenius, O.; Papanicolaou, A.; Garbutt, J.S.; Eleftherianos, I.; Huvenne, H.; Kanginakudru, S.; Albrechtsen, M.; An, C.; Aymeric, J.L.; Barthel, A.; et al. RNA interference in Lepidoptera: An overview of successful and unsuccessful studies and implications for experimental design. J. Insect Physiol. 2011, 57, 231-245. [CrossRef]

36. Joga, M.R.; Zotti, M.J.; Smagghe, G.; Christiaens, O. RNAi efficiency, systemic properties, and novel delivery methods for pest insect control: What we know so far. Front. Physiol. 2016, 7, 553. [CrossRef]

37. Roberts, A.F.; Devos, Y.; Lemgo, G.N.; Zhou, X. Biosafety research for non-target organism risk assessment of RNAi-based GE plants. Front. Plant Sci. 2015, 6, 958. [CrossRef] 